\title{
The Influence of Financial Technology Adoption into Borrower Satisfaction Using Trust as Mediating Variable
}

\author{
Andy Firmansyah ${ }^{1}$, Florentina Kurniasari², Winarno ${ }^{3}$ \\ \{andy.firmansyah@umn.ac.id ${ }^{1}$, florentina@umn.ac.id², pmwinarno@umn.ac.id $\left.{ }^{3}\right\}$ \\ Management Technology, Universitas Multimedia Nusantara, Indonesia, Kampus UMN, Scientia Garden, J1. Boulevard \\ Gading Serpong, Tangerang, Banten ${ }^{1}$, \\ Management Technology, Universitas Multimedia Nusantara, Indonesia, Kampus UMN, Scientia Garden, Jl. Boulevard \\ Gading Serpong, Tangerang, Banten ${ }^{2}$, \\ Informatics, Universitas Multimedia Nusantara, Indonesia, Kampus UMN, Scientia Garden, Jl. Boulevard Gading \\ Serpong, Tangerang, Banten ${ }^{3}$
}

\begin{abstract}
The tremendous growth of internet user in all across the country opened a big opportunity for the financial institution to offer the financial facilities using the internet technology. The fintech companies gained popularity among this segment since they are able to offering the loan without any collateral in more simple administrative procedure and in a speedy time. But, the fintech companies also had limitation in terms of nominal loan amount that could be disbursed to the borrowers. The number of respondents who have filled out the questionnaire in this study is 103 respondents with various educational backgrounds, income, business fields, and the amount of capital loan proposed. This research analyze the effect of the adoption of financial technology on trust, the adoption of financial technology on borrower satisfaction, trust on financial inclusion, and trust. as a mediation of the relationship between the adoption of financial technology on the borrower satisfaction.
\end{abstract}

Keywords: Financial Technology, Borrower Satisfaction, Trust, SME's, Start up Company, Adoption Technology, Peerto-peer lending.

\section{Introduction}

As one of the populous country in the world, Indonesia experienced the significant disparity between people income and expenditures. In the year 2019, the average monthly expenditures for consumption especially in Java island was at range between 1.1 million to 1.8 million Rupiahs. That expenditure excludes for housing, utilities, education, healthcare and other primary needs. Meanwhile, the average monthly income was at range between 1.5 million to 3.5 million Rupiahs [1]. Therefore, many Indonesians had highly dependent with the third parties that could give financial assistance to fulfill their needs. Many financial institutions include bank as a formal financial institution, cooperatives or financial technology (fintech) offered the financing scheme. The tremendous growth of internet user in all across the country opened a big opportunity for the financial institution to offer the financial facilities using the internet technology. In 2018, there was 95.3 million internet user in Java island and the number is expected to grow at $30 \%$ per year.

Recent data showed that there are 164 registered financial technology companies in Indonesia [2]. The fintech companies choose the micro segment or Small Medium Enterprise (SME's) as their main customer base. The fintech companies gained popularity among this segment since they are able to offering the loan without any collateral in more simple administrative procedure and in a speedy time. But, the fintech companies also had limitation in terms of nominal loan amount that could be disbursed to the borrowers. Therefore, Financial Service Authority (OJK) released an innovative financial regulation No. 13/POJK.02/2018 to mitigate the financial risks, maintain the economic stability through financial product digitalization and increase financial literacy to protect the customer interest [3]. The government expected that the fintech companies could collaborate with the other financial institution to achieve $75 \%$ targeted of financial inclusion in the year 2020 . 
To achieve this target, fintech companies must pay attention to fulfilling borrower satisfaction. Technology adoption has a significant effect on debtor satisfaction in the financing industry [4]. The adoption technology itself was greatly affected by the service, information and system quality of the technology [5]. Borrower who enjoyed a memorable experiences when adopting the technology would trust with the new technology [6]. The trust feeling would created the borrower satisfaction of the new technology [7]. Once the borrower satisfied with the technology, they are willing to use the application [8]. This study is trying to analyze the influence of fintech adoption into borrower satisfaction using trust as mediating variable.

\section{Literature Review}

\section{Micro-Credit Financing}

Microfinance refers to agreements with borrowers and financial institutions (banks or fintech companies) [9]. Financial institutions provide funds and the borrower will pay the nominal loan and interest at a certain time [10]. The micro credit financing segment is SMEs that need loans to develop their business. Fintech companies use advances in information technology to offer loans to the micro segment.

\section{Financial Technology}

Financial technology as the use of technology in conducting financial transactions [11]. Fintech exists as an innovative collaboration between financial and technological features [12]. There are many types of fintech, but the most popular is the peer-to-peer lending platform.

\section{Financial Technology Adoption}

The Technology-Organization-Environment (TOE) theory explains that there are three factors that influence the adoption of technology in an organization, namely: technology, organization and environment [13]. In the financial technology industries there were three factors that gave significant impact into trust. Those three factors of financial technology adoption were service quality, information quality and system quality. Service quality was defined as the level of services delivered by the organization in order to meet the customer expectation [14]. Service quality had five dimensions, including Reliability, Responsiveness, Assurance, Empathy and Tangible. Reliability was an accurate services given to the borrower without any mistakes. Reliability also referred to the ability of the organization in delivering on-time services. Responsiveness referred to the availability of the fintech companies in giving the right information at the right time. Assurance was the ability of the organization to increase the trust and secure feeling for the borrower by equipping the sales agent with adequate product knowledge. Empathy was the fintech company ability to understand and giving the solution of each borrower's problems. Meanwhile, tangible referred to the attractive of physical facilities, employee appearances, equipment and other supporting materials used by the fintech company in giving the services to the borrower.

Information Quality defined as the measurement of the content quality of an information system [15]. The quality of information relating to the value used which can be used to create an information from an existing system [16]. The better information that could be shared by the fintech company would increase the borrower trust in using the facilities. There are three main dimensions of information quality, namely: Accuracy, Timeliness and Relevance. Accuracy means that all information describes the actual conditions and does not mislead the borrower. Timeliness refers to the production of information as a result of data at the right time. This information can be relevant if it provides benefits to the borrower as the recipient of the information. [17] System quality can be used to measure information systems [18] and system quality have five dimensions which include: reliability, flexibility, integration, accessibility, and system time responsiveness. [6]

\section{Trust}

Borrower trust would be created if the fintech organization able to provide the services to the borrowers higher than their expectation. The trust built by some elements, including the ability or competence of the sales agents who are directly interacted with the borrowers; the integrity or commitment from the organization in doing the business and goodwill of the organization in delivering the services to the borrowers. 


\section{Borrower Satisfaction}

Borrower satisfaction defined as a customer's feeling after consuming the product or services [19]. Higher borrower satisfaction would arise if the products or services performances exceeding their expectation. On the contrary, the low borrower satisfaction would arise if the products or services performances was delivered lower than their expectation.

Based on the explanation of the literature review above, this study was able to create a proposed theoretical framework as follows:

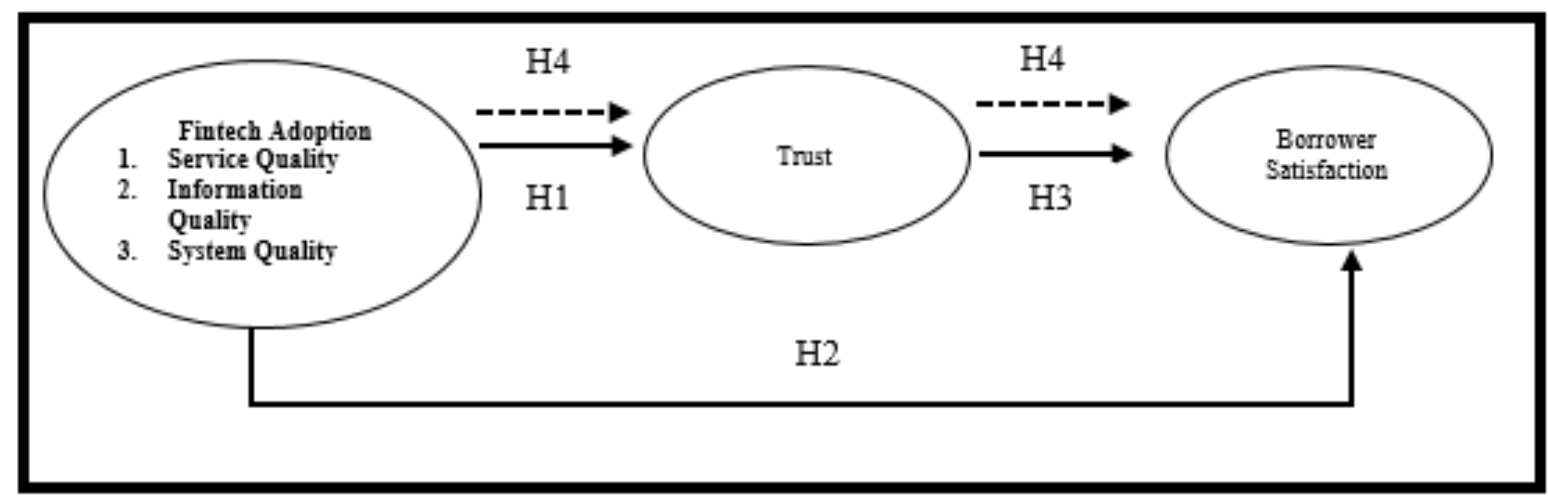

Fig. 1. Theoretical Framework

From the theoretical framework above, this study was also able to develop the hypotheses as follows:

H1: There is a positive influence of financial technology adoption into trust

$\mathrm{H} 2$ : There is a positive influence of financial technology adoption into borrower satisfaction.

H3: There is a positive influence of trust into borrower satisfaction

H4: Trust as a mediating variable from the relationship between financial technology into borrower satisfaction.

\section{Research Methodology}

As a quantitative research, the research is trying to analyze the relationship among variables [20]. The population of this research is all the borrower who already had loan from the fintech companies. Meanwhile, the sample of this study was the SME's as the existing borrower of one of the biggest fintech companies in Indonesia (Modalku). Modalku was chosen because this peer-to-peer lending platform had a best reputation in Indonesia in delivering superior quality to the borrowers. A purposive sampling was used to decide the criteria of the respondents. The respondents had to meet the requirement decided by the researcher, such as: the SME's was an existing borrower of the Modalku with the average sales revenue of 5 millions Rupiah a month and domiciled in the areas of Jabodetabek. The minimum sample used is equivalent to 5: 1 . There are 15 indicators used in this study and the minimum sample required is $15 \times 5=75$ respondents. The researcher decided to assign an online questionnaire via google form to 103 respondents to get more generalizations. Respondents must answer closed questions on a Likert scale of 1-5. [21]

Table 1. Table of Indicators

(All data collection would be further analyzed with Structural Equation Method (SEM).

\begin{tabular}{|c|c|c|c|c|c|}
\hline R1 & R2 & R3 & DT1 & DT2 & DT3 \\
\hline $\begin{array}{c}\text { The suitable loan } \\
\text { information }\end{array}$ & $\begin{array}{c}\text { Clear loan } \\
\text { information }\end{array}$ & $\begin{array}{c}\text { Competence of } \\
\text { the sales agent }\end{array}$ & $\begin{array}{c}\text { Proper } \\
\text { information } \\
\text { available to the } \\
\text { borrower }\end{array}$ & $\begin{array}{c}\text { Assisting } \\
\text { borrower's } \\
\text { problems }\end{array}$ & $\begin{array}{c}\text { Solving the } \\
\text { borrower } \\
\text { difficulties }\end{array}$ \\
\hline
\end{tabular}




\begin{tabular}{|c|c|c|c|c|c|}
\hline J1 & $\mathbf{J} 2$ & J3 & E1 & E2 & $\mathbf{E 3}$ \\
\hline $\begin{array}{c}\text { Professionalism of the } \\
\text { agents }\end{array}$ & $\begin{array}{l}\text { The agent } \\
\text { capabilities }\end{array}$ & $\begin{array}{l}\text { Transaction } \\
\text { security }\end{array}$ & $\begin{array}{l}\text { Protection of } \\
\text { borrower interest }\end{array}$ & $\begin{array}{l}\text { Easiness to } \\
\text { contact }\end{array}$ & $\begin{array}{l}\text { Standard in } \\
\text { giving services } \\
\text { to the borrower }\end{array}$ \\
\hline BF1 & BF2 & A1 & A2 & TW1 & TW2 \\
\hline $\begin{array}{l}\text { Good appearance of } \\
\text { the sales agent }\end{array}$ & $\begin{array}{l}\text { Informative } \\
\text { brochures and } \\
\text { other services }\end{array}$ & $\begin{array}{c}\text { Accuracy } \\
\text { variable was } \\
\text { indicated with } \\
\text { the accuracy }\end{array}$ & $\begin{array}{c}\text { Suitable } \\
\text { information fit } \\
\text { with the } \\
\text { borrower needs }\end{array}$ & $\begin{array}{c}\text { Availability of } \\
\text { loan } \\
\text { information }\end{array}$ & $\begin{array}{l}\text { Loan } \\
\text { repayment }\end{array}$ \\
\hline RE1 & RE2 & FS1 & FS2 & IS1 & IS2 \\
\hline $\begin{array}{l}\text { Loan information } \\
\text { related with the } \\
\text { borrower needs }\end{array}$ & $\begin{array}{l}\text { Loan facilities } \\
\text { related with the } \\
\text { capabilities of } \\
\text { the customer }\end{array}$ & $\begin{array}{l}\text { Flexible loan } \\
\text { application }\end{array}$ & Borrower needs & $\begin{array}{c}\text { System } \\
\text { integration } \\
\text { related with the } \\
\text { interactive }\end{array}$ & $\begin{array}{l}\text { Simple loan } \\
\text { application }\end{array}$ \\
\hline AK1 & AK2 & IN1 & IN2 & KDP1 & KDP2 \\
\hline $\begin{array}{l}\text { Easy access loan } \\
\text { application through } \\
\text { smartphone }\end{array}$ & $\begin{array}{l}\text { Loan repayment } \\
\text { facilities }\end{array}$ & $\begin{array}{l}\text { Important } \\
\text { information } \\
\text { provided to the } \\
\text { borrowers }\end{array}$ & $\begin{array}{l}\text { Keeping } \\
\text { borrower } \\
\text { reputation }\end{array}$ & $\begin{array}{l}\text { Keeping the } \\
\text { borrower data } \\
\text { security }\end{array}$ & $\begin{array}{l}\text { Responsible for } \\
\text { borrower loan }\end{array}$ \\
\hline PK1 & PK2 & PK3 & KMLSH1 & KMLSH2 & \\
\hline $\begin{array}{l}\text { The loan purpose for } \\
\text { expand the business }\end{array}$ & $\begin{array}{c}\text { Suitable for } \\
\text { sme's business }\end{array}$ & $\begin{array}{l}\text { The borrower } \\
\text { would } \\
\text { recommend } \\
\text { modalku }\end{array}$ & $\begin{array}{l}\text { Borrower } \\
\text { satisfied with the } \\
\text { loan application }\end{array}$ & $\begin{array}{l}\text { Borrowers had } \\
\text { the services as } \\
\text { expected }\end{array}$ & \\
\hline
\end{tabular}

\section{Findings \& Discussion}

Pre-test analysis of 30 respondents showed that all variables were valid since the value of KMO, MSA and factor loading of each variable $>0.5$. Meanwhile, the reliability testing showed that all variables were reliable since Cronbach's Alpha $>0.75$, with service quality had the highest value (0.96) and borrower satisfaction had the lowest value (0.873).

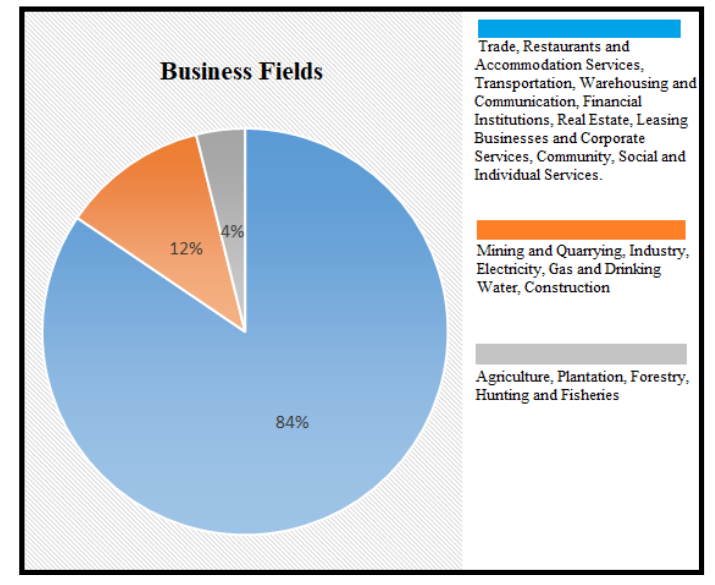

Figure 2. Business Fields

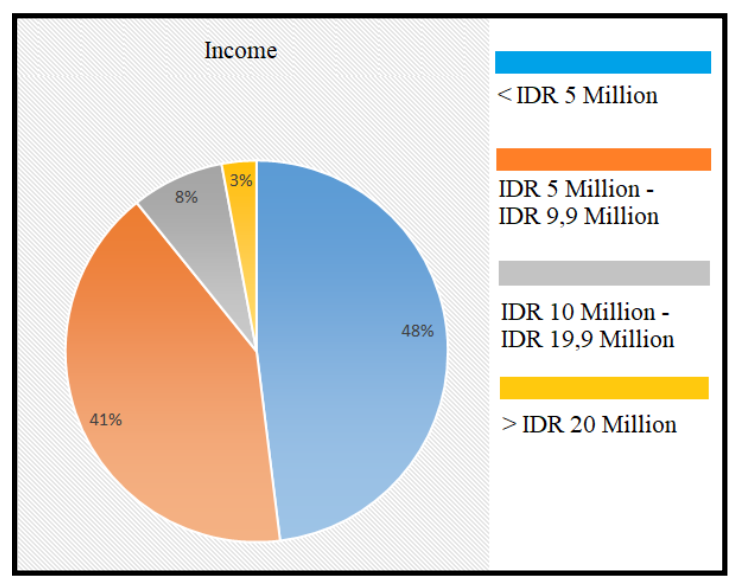

Figure 3. Income

The number of respondents who have filled out the questionnaire in this study is 103 respondents with various educational backgrounds, income, business fields, and the amount of capital loan proposed. From 103 respondents, the researcher took 100 respondents according to the respondent screening requirements for this study including respondents who are domiciled in DKI Jakarta, Tangerang Regency, Tangerang City and South Tangerang City, have a smartphone and have become borrowers in Modalku. 
The results obtained from the respondent profile based on the following business fields: there are $84 \%$ of respondents in the business fields of trade, restaurants and accommodation services, transportation, warehousing and communication, financial institutions, real estate, rental business and corporate services, Community, Social and Individual Services, $12 \%$ of the respondents are in the mining and quarrying, industry, electricity, gas and drinking water, construction, and $4 \%$ of the respondents are in the agriculture, plantation, forestry, hunting and fishery business sectors. The results obtained by the profile of respondents based on monthly income are as follows: there are $47 \%$ of respondents with monthly income <IDR 5 million, $41 \%$ of respondents with a monthly income of IDR 5 million - IDR 9.9 million, $8 \%$ of respondents with a monthly income of IDR 10 million - IDR 19, 9 million, and 4\% of respondents with a monthly income above IDR 20 million. Based on the table of structural model test results, it can be seen that SEM (Structural Equation Model) analysis involves several fit index tests to show the suitability between the data obtained by the researcher and the model that has been described in the structural model. The following is the result of the fit index for the entire model in the calculation of the SEM (Structural Equation Model) using AMOS version 24. The test results of the structural model can be seen from the direct effect of each research indicator on the related variables. From the Financial Technology Adoption variable, the smallest indicator effect is the E3 indicator with an effect value of 0.921 and the greatest influence on the DT1 indicator with an effect value of 1.212. In the trust indicator variable with the smallest level of influence is on the IN1 indicator with an influence value of 0.995 and the indicator with the greatest influence is on the KDP1 indicator with an influence value of 1.078. The Borrower Satisfaction variable has an indicator with the lowest influence value, namely the PK1 indicator with a number of 0.998 and the indicator with the highest influence on PK2 with a number of 1.106. The results of hypothesis testing from this study show that the adoption of financial technology has a positive effect on borrower satisfaction. Financial Technology is the use of technology in finance and has many advantages in doing business, especially for small businesses. Fintech users will get easy transactions and get online loan funds [22]. Fintech can increase public financial inclusion and financial stability [23]. The driving factor for using fintech is ease of features, social influence, performance expectations, and system security. [24] In this study, borrower satisfaction is highly dependent on the adoption of financial technology which includes service, information and system quality. The results of hypothesis testing from this study indicate that the adoption of financial technology has a positive effect on trust.

This is because the frequency of answers shows a good and positive attitude from the services, information and systems provided by the company that fosters a sense of trust in the borrower. Research shows that there is a positive relationship between service quality and consumer trust.[25] Service quality also has a positive effect on consumer trust. [26] So that borrowers who have received services in accordance with expectations will generate trust in the company. The results of hypothesis testing from this study show that trust has a positive effect on borrower satisfaction. This is because the frequency of answers indicates a good and positive attitude from the borrower who has entrusted the company's services for his business interests. Service quality is the level of excellence expected and the control over the excellence expected to fulfill customer desires.[14] So the conclusion is from the superior service provided by the company to borrowers, there is confidence so that the borrower is always fulfilled at every request.

\section{Conclusion}

This study entitled "The Influence Of Financial Technology Adoption Into Borrower Satisfaction Using Trust As Mediating Variable" by analyzing the effect of the adoption of financial technology on trust, the adoption of financial technology on borrower satisfaction, trust on financial inclusion, and trust. as a mediation of the relationship between the adoption of financial technology on the borrower satisfaction. This research is expected to provide benefits and educate the public in order to obtain easy financial facilities for doing business.

Acknowledgements: We would like to thank Direktorat Riset dan Pengabdian Masyarakat (DRPM) from Kementerian Riset, Teknologi dan Pendidikan Tinggi for funding this research through the scheme Penelitian Terapan Unggulan Perguruan Tinggi (PTUPT). 


\section{REFERENCES}

[1] Badan Pusat Statistik, "Pendapatan dan Pengeluaran Penduduk Indonesia 2017 - 2019," 2020. [Online]. Available: https://www.bps.go.id/subject/5/konsumsi-dan-pengeluaran.html.

[2] Otoritas Jasa Keuangan, "Data Jumlah Bank di Indonesia," 2020. [Online]. Available: https://www.ojk.go.id/id/kanal/perbankan/data-dan-statistik/statistik-perbankan-indonesia/default.aspx.

[3] Otoritas Jasa Keuangan, "Dasar Kriteria Usaha UMKM," 2008. [Online]. Available: https://www.ojk.go.id/sustainable-finance/id/peraturan/undang-undang/Pages/Undang-Undang-RepublikIndonesia-Nomor-20-Tahun-2008-Tentang-Usaha-Mikro,-Kecil,-dan-Menengah.aspx\#: :text=Kecil\%2C dan Menengah-,Undang-Undang Nomor 20 Tahun 2008,Usaha Mikro\%2C K.

[4] S. C. Hsueh and C. H. Kuo, "Effective matching for P2P lending by mining strong association rules," 2017, doi: $10.1145 / 3133811.3133823$.

[5] R. . Freedman, "Introduction to Financial Technology," Acad. Press, 2006.

[6] R. R. Nelson, P. A. Todd, and B. H. Wixom, "Antecedents of information and system quality: An empirical examination within the context of data warehousing," J. Manag. Inf. Syst., 2005, doi: 10.1080/07421222.2005.11045823.

[7] J. Sahanggamu, Stefhanie; Mananeke, Lisbeth; Sepang, “ANALISIS KUALITAS LAYANAN, SERVICESCAPE DAN KEPERCAYAAN TERHADAP KEPUASAN NASABAH PADA PT. BANK SINARMAS BITUNG,” J. EMBA J. Ris. Ekon. MANAJEMEN, BISNIS DAN Akunt., vol. 3, no. 1, pp. 1084 $1095,2015$.

[8] A. Gul, S. Aamir, S. Jafery, J. Rafiq, and H. Naeem, "Improving Employees Performance Through Total Quality Management," Int. J. Econ. Manag. Sci., 2012.

[9] Kasmir, "Kasmir," in PENGANTAR MANAJEMEN KEUANGAN, 2010.

[10] M. S. P. Hasibuan, "Manajemen Sumber Daya Manusia," Ed. Revisi Jakarta Bumi Aksara, 2011.

[11] D. W. Arner, J. N. Barberis, and R. P. Buckley, "The Evolution of Fintech: A New Post-Crisis Paradigm?," SSRN Electron. J., 2015, doi: 10.2139/ssrn.2676553.

[12] M. M. Pribadiono, Hukum, Esa, \& Barat. (2016, "Pribadiono, Hukum, Esa, \& Barat. (2016, Maret Minggu)," 2016. www.coursehero.com.

[13] L. Tornatzky and M. Fleischer, The process of technology innovation. 1990.

[14] F. Tjiptono and G. Chandra, "Service, Quality \& Satisfaction," in Edisi 4, 2011.

[15] C. S. Ong, M. Y. Day, and W. L. Hsu, "The measurement of user satisfaction with question answering systems," Inf. Manag., 2009, doi: 10.1016/j.im.2009.07.004.

[16] S. Negash, T. Ryan, and M. Igbaria, "Quality and effectiveness in Web-based customer support systems," Inf. Manag., 2003, doi: 10.1016/S0378-7206(02)00101-5.

[17] H. M. Jogiyanto, "Analisis \& Desain: Pendekatan Terstruktur, Teori dan Praktik Aplikasi Bisnis," Yogyakarta Andi, 2005.

[18] S. Chen, X. Chen, Q. Cheng, and T. Shevlin, "Are family firms more tax aggressive than non-family firms?," J. financ. econ., 2010, doi: 10.1016/j.jfineco.2009.02.003.

[19] P. Kotler, "Manajemen Pemasaran di Indonesia," in Manajemen Pemasaran di Indonesia, 2000.

[20] J. W. Creswell, Riset Pendidikan: Perencanaan, Pelaksanaan, dan Evaluasi Riset Kualitatif dan Kuantitatif. 2015.

[21] J. F. Hair, W. C. Black, B. J. Babin, and R. E. Anderson, Multivariate Data Analysis Seventh Edition. 2014.

[22] A. Billion, FinTech for micro, small and medium sized enterprises. ING Economic Department, 2016.

[23] P. K. Ozili and E. Outa, "Bank loan loss provisions research: A review," Borsa Istanbul Review. 2017, doi: 10.1016/j.bir.2017.05.001.

[24] W. Boonsiritomachai and K. Pitchayadejanant, "Determinants affecting mobile banking adoption by generation Y based on the unified theory of acceptance and use of technology model modified by the technology acceptance model concept," Kasetsart J. Soc. Sci., 2019, doi: 10.1016/j.kjss.2017.10.005.

[25] P. F. Chou, C. S. Lu, and Y. H. Chang, "Effects of service quality and customer satisfaction on customer loyalty in high-speed rail services in Taiwan," Transp. A Transp. Sci., 2014, doi: 10.1080/23249935.2014.915247.

[26] M. Budi Setiawan and U. Ukudi, "Pengaruh Kualitas Layanan, Kepercayaan Dan Komitmen Terhadap Loyalitas Nasabah ( Studi Pada Pd. Bpr Bank Pasar Kendal)," J. Bisnis dan Ekon. (JBE), Sept. 2007, Hal. 215-227 Vol.14, No.2, 2007. 